\title{
Az aortobiiliacalis occlusiv érbetegség miatt végzett aortobifemoralis bypass mútétek hosszú távú eredményeinek elemzése
}

\author{
Pomozi Enikő oh. ${ }^{1}$ - Lengyel Balázs dr. ${ }^{2}$ - Osztrogonácz Péter dr. ${ }^{2}$ \\ Nguyen Dat Tin dr. ${ }^{3}$ - Szeberin Zoltán dr. ${ }^{2}$ \\ ${ }^{1}$ Semmelweis Egyetem, Általános Orvostudományi Kar, Budapest \\ ${ }^{2}$ Semmelweis Egyetem, Városmajori Szív- és Érgyógyászati Klinika, \\ Érsebészeti és Endovaszkuláris Tanszék, Budapest \\ ${ }_{3}^{3}$ Semmelweis Egyetem, Általános Orvostudományi Kar, Városmajori Szív- és Érgyógyászati Klinika, Budapest
}

\begin{abstract}
Bevezetés: A diffúz aortobiiliacalis érszakasz occlusiv betegségének kezelésére alkalmazott aortobifemoralis bypass szerepe csökken az endovascularis mútétek térnyerése miatt.

Célkitüzés: A vizsgálat célja volt a modern invazív kezelés korszakában a perioperatív és a hosszú távú eredmények elemzése aortobiiliacalis bypass után, melyek összehasonlíthatók az endovascularis megoldások eredményeivel.

Módszerek: A retrospektív, egycentrumú vizsgálat során a Semmelweis Egyetem Városmajori Szív- és Érgyógyászati Klinikájának Érsebészeti és Endovaszkuláris Tanszékén 2006. 01. 01. és 2017. 12. 31. között occlusiv aortoiliacalis atherosclerosis miatt primer aortobifemoralis bypass mútéten átesett 419 beteg (átlagéletkor: 62,2 év, SD: \pm 8,22; 224 férfi, $53 \%$ ) adatait elemeztük.

Eredmények: A posztoperatív 30 napon belüli mortalitás 5,01\%, a késői mortalitás 10,98\% és 29,59\% volt 12, illetve 60 hónap után. A betegek 12,57\%-ánál történt korai reoperáció, késői reoperáció 32 (8\%) betegnél vált szükségessé. A graft elsődleges nyitva maradása $88,65 \%$ és $81,15 \%$ volt 12, illetve 60 hónap után. 21 betegnél történt amputáció (6,29\%); 57,14\%-ban femoralis, 35,71\%-ban cruralis szinten, 7,14\%-ban a boka szintje alatt. Az amputációkra 35,71\%-ban a bypasst követő 30 napon belül, további 35,71\%-ban 2 éven belül került sor. Az esetek 35,63\%-ában lépett fel egyéb szövődmény; a leggyakoribbak: műtétet igénylő posztoperatív hernia $(6,89 \%)$, cardiovascularis szövődmény $(4,19 \%)$, lágyéki nyirokcsorgás vagy sebgyógyulási zavar $(4,79 \%)$.

Következtetés: Eredményeink alapján e betegcsoportban az aortobifemoralis bypass elfogadható, de nem jelentéktelen perioperatív halálozással és magas morbiditással jár. A graft hosszú távú nyitva maradása jó, de az újabb érmútét mind rövid, mind hosszú távon relatíve gyakori. A kevésbé invazív technikák eredményeinek összehasonlítása indokolt a hosszú szakaszú (TASC C, D) elváltozások esetén.
\end{abstract}

Orv Hetil. 2021; 162(3): 99-105.

Kulcsszavak: aortoiliacalis elzáródás, aortobifemoralis bypass mútét, atherosclerosis

\section{Long-term analysis of the results of aorto-bifemoral bypass surgery for diffuse aorto-biiliac occlusive disease}

Introduction: The role of aorto-bifemoral bypass in the treatment of diffuse aorto-biiliac occlusive disease decreases in the era of endovascular surgery.

Objective: The aim of the study was to analyse the early and long-term postoperative results of aorto-bifemoral bypass in a recent time period. These results may be used as a baseline to compare the results of endovascular procedures. Methods: In a retrospective, single-center study, the data of 419 patients (mean age: 62.2 years, SD: $\pm 8.22 ; 224$ men, $53 \%$ ) who underwent primary aorto-bifemoral bypass due to occlusive aorto-iliac atherosclerosis from 01. 01.2006 to 31. 12. 2017 at the Department of Vascular and Endovascular Surgery of Semmelweis University Heart and Vascular Center were analysed. 
Results: Postoperative mortality within 30 days was $5.01 \%$, late mortality was $10.98 \%$ and $29.59 \%$ after 12 and 60 months, respectively. $12.57 \%$ of the patients needed early reoperation and late reoperation was required in 32 cases (8\%). The primary graft patency was $88.65 \%$ and $81.15 \%$ after 12 and 60 months, respectively. 21 patients underwent amputation $(6.29 \%) ; 57.14 \%$ at the femoral level, $35.71 \%$ at the crural level and $7.14 \%$ below the ankle level. Amputations were performed in $35.71 \%$ of the cases within 30 days after the bypass and an additional $35.71 \%$ within 2 years. Other complications occurred in $35.63 \%$ of the cases; the most common causes were postoperative hernia requiring surgery $(6.89 \%)$, cardiovascular complication $(4.19 \%)$ and inguinal wound healing disorders $(4.79 \%)$.

Conclusion: Based on our results, aorto-bifemoral bypass surgery is associated with acceptable but not insignificant perioperative mortality and high morbidity in this group of patients. The graft patency is favourable in the long term, however, additional vascular reintervention is common in short and long term as well. Short- and long-term results of percutaneous endovascular techniques in diffuse aorto-biiliac disease (TASC C and D lesions) are suggested to be compared to these recent results of open surgery.

Keywords: aorto-iliac occlusion, aorto-bifemoral bypass surgery, atherosclerosis

Pomozi E, Lengyel B, Osztrogonácz P, Nguyen DT, Szeberin Z. [Long-term analysis of the results of aorto-bifemoral bypass surgery for diffuse aorto-biiliac occlusive disease]. Orv Hetil. 2021; 162(3): 99-105.

(Beérkezett: 2020. június 25.; elfogadva: 2020. július 31.)

\section{Rövidítések}

$\mathrm{ABB}=$ aortobifemoralis bypass; $\mathrm{AIOD}=($ aorto-iliac occlusive disease) aortoiliacalis occlusiv betegség; LEAD $=$ (lowerextremity arterial disease) alsó végtagi artériás betegség; PTFE = politetrafluor-etilén; $\mathrm{SD}=$ standard deviáció; TASC $=$ TransAtlantic Inter-Society Consensus

Az alsó végtagi artériás betegség (lower-extremity arterial disease - LEAD) ma világszerte $>200$ millió embert érint, a betegség incidenciája és prevalenciája az elmúlt évtizedben gyors növekedést mutatott. Míg korábban a magas jövedelmú országokban volt nagyobb az incidenciája, mostanában a népesség átlagéletkorának és a különböző kockázati tényezőknek a növekedése miatt (hasi elhízás, az ahhoz kapcsolódó anyagcsere-rendellenességek) a betegség előfordulása az alacsonyabb és közepes jövedelmú országokban - mint Magyarország - is jelentősen növekedett.

$\mathrm{Az}$ aortoiliacalis occlusiv betegség (AIOD) a LEAD részeként az alsó végtag keringésének proximális anatómiai szintjén jelentkezik. Ebben az esetben a distalis aortára és az arteria iliaca erekre lokalizálódik a szúkület vagy elzáródás, bár a betegség progressziójának előrehaladtával később a distalis (lágyékszalag alatti) keringési szegmensek is érintettek lehetnek [1]

Az állapot fontosságát adja, hogy e betegcsoportban gyakran kerül sor major alsó végtagi amputációra (combvagy lábszárszinten), és az ezzel kapcsolatos halálozás száma nem csökkent hazánkban jelentősen az elmúlt évtizedekben. Fontos továbbá a jelentős életminőség-csökkenés, mely komoly emocionális és anyagi teher a betegnek, környezetének és az egészségügyi ellátórendszernek. Emellett a betegségben szenvedők körében fokozott a súlyos szövődmények előfordulásának kockázata, elsősorban a cardiovascularis és cerebrovascularis eseménye- ké, a szívkoszorúerekben, a carotisartériákban és az agyi kiserekben egyidejúleg jelen lévő atherosclerosis miatt.

A hosszú szakaszú (TASC C, D) [2] occlusiv elváltozás esetén az arany standard eljárás $\mathrm{ma}$ is az aortobifemoralis bypass $(\mathrm{ABB})$, melynek mútéti technikája az utóbbi évtizedekben kikristályosodott, az intenzív ellátás fejlődésével a perioperatív mortalitás csökkent. Az endovascularis beavatkozások száma azonban növekszik a hosszú szakaszú elzáródások, szúkületek esetén is, a technikai eszközök fejlődésével és az endovascularis tapasztalat növekedésével párhuzamosan. Továbbra sincsenek egyértelmú ajánlások, melyek ezekben az esetekben állást foglalnának a nyitott mútét vagy az endovascularis technika alkalmazása mellett.

\section{Célkitüzés}

Célunk volt, hogy meghatározzuk az AIOD miatt primer ABB-mútéten átesett betegek perioperatív halálozásának rizikótényezőit, a mútét utáni komplikációk és a graft nyitva maradásának arányát. Emellett vizsgáltuk a reoperációk arányát, azok okait és időbeli megoszlását.

\section{Módszerek}

A 12 évet magában foglaló időintervallum (2006. 01. 01.-2017. 12. 31.) során 419 AIOD-beteget operáltak a Semmelweis Egyetem Városmajori Szív- és Érgyógyászati Klinikájának Érsebészeti és Endovaszkuláris Tanszékén ABB-megoldással. A 419 betegből 334-től tudtunk a hosszú távú statisztikai elemzéshez releváns adatokat szerezni, ami 80\%-os utánkövetési arányt eredményezett. A követés időtartama átlagosan $52(\mathrm{SD}: \pm 38,06)$ hónap volt. Az adatokat a klinika elektronikus (MedSol) és papíralapú dokumentációjából gyújtöttük: anamnézis, a mútét indikációját képező érszakasz morfológiai sajá- 
tosságait leíró angiográfiás leletek, részletes mütéti leírások, aneszteziológiai jegyzőkönyvek, a posztoperatív kontrollvizsgálatok eredményei, valamint részletes boncjegyzőkönyvek. A páciensektől, illetve hozzátartozóiktól telefonos interjúk során további információkat nyertünk a kórházi nyilvántartásban nem szereplő, más egészségügyi intézményekben történt vizsgálatokról és terápiás beavatkozásokról, azok kimeneteléról és a betegek aktuális állapotáról. Ezekből az adatokból a későbbiek során ismertetett eredményeinket Excel-függvényekkel és a program klinikai statisztikában használt bővítményeinek segítségével (Microsoft Corporation, Redmond, WA, USA), valamint Fisher-féle egzakt teszt alkalmazásával, $\mathrm{p}=$ 0,05-ös szignifikanciaszint mellett kaptuk meg.

Munkánkat a Semmelweis Egyetem Regionális, Intézményi Tudományos és Kutatásetikai Bizottsága által kiadott, 102/2018. számú engedély alapján végeztük. Adatkezelési és feldolgozási tevékenységünk során maradéktalanul figyelembe vettük az 1997. évi XLVII. törvény 21 . $\$$-át az egészségügyi és a hozzájuk kapcsolódó személyes adatok kezeléséről és védelméről, valamint az információs önrendelkezési jogról és az információszabadságról szóló 2011. évi CXII. törvényt.

\section{Eredmények}

AIOD miatt primer ABB-mútéten átesett 419 beteg (átlagéletkor: 62,2 év, SD: $\pm 8,22 ; 224$ férfi, 53\%) adatait elemeztük. Az egyéb indikáció, például aortoiliacalis aneurysma miatt végzett $\mathrm{ABB}$-mútéteket nem vettük figyelembe vizsgálatunk során, így az ilyen betegek adatait nem dolgoztuk fel.

A páciensek 54,42\%-ánál a betegség izoláltan az aortoiliacalis szakaszt érintette.

Az esetek nagy része a Fontaine IIb $(61,34 \%)$ kategóriába tartozott (200 $\mathrm{m}$ alatti dysbasia), 34,46\%-ban pe-
1. táblázat | Nyitvamaradási adatok

\begin{tabular}{lccccc}
\hline & 1 hónapos & 1 éves & 2 éves & 5 éves & 10 éves \\
\hline Elsődleges & $91,62 \%$ & $88,65 \%$ & $85,29 \%$ & $81,15 \%$ & $62,96 \%$ \\
Másodlagos & $93,11 \%$ & $94,79 \%$ & $87,50 \%$ & $84,75 \%$ & $68,15 \%$ \\
Harmadlagos & $94,01 \%$ & $96,32 \%$ & $89,34 \%$ & $86,07 \%$ & $69,63 \%$ \\
\hline
\end{tabular}

dig krónikus, kritikus végtagischaemia (Fontaine IIIIV.) miatt történt a mütét.

A beavatkozások többsége krónikus ischaemia miatt történt: elektív mütét $66 \%$, sürgető eset $30 \%$, akut beavatkozás 4\%. A mütétet 14 esetben retroperitonealis transmuscularis, a többi esetben transperitonealis feltárásból végezték. Az áthidalás 98,2\%-ban Dacron grafttal történt, a többi esetben PTFE, illetve ezüsttel impregnált Dacron graft került beültetésre. A kiterjedt, diffúz alapbetegség miatt 12 páciens esetében volt szükség a távolabbi érszakasz szimultán bypassmütétére is (femoropoplitealis szakasz). A posztoperatív hospitalizáció ideje az osztályon átlagosan $9(\mathrm{SD}: \pm 4,83)$, az intenzív osztályon 2,5 (SD: $\pm 2,8)$ nap volt.

A fontosabb rizikótényezőket, kísérő betegségeket és releváns anamnesztikus adatokat az 1 d ábra mutatja. Általánosságban multimorbid betegekról van szó: minden páciens esetében átlagosan 4 rizikófaktort azonosítottunk, melyek emelhetik a posztoperatív szövődmények kialakulásának kockázatát.

Az 1. táblázat és a 2. ábra a graft nyitvamaradási adatait összesíti az idő függvényében. Az elsődleges 1 hónapos nyitva maradás 91\%, az 5. év végén $81,15 \%$.

A korai reoperációk aránya $12,57 \%$, míg a késői reoperációké 9,58\%. A korai és késői reoperációk leggyakoribb oka egyaránt a restenosis/occlusio. A korai reoperációk gyakori okai még a vérzések $(31,25 \%)$ és a graftinfekció $(4,17 \%)$. A késői reoperációk között a vérzéses esetek

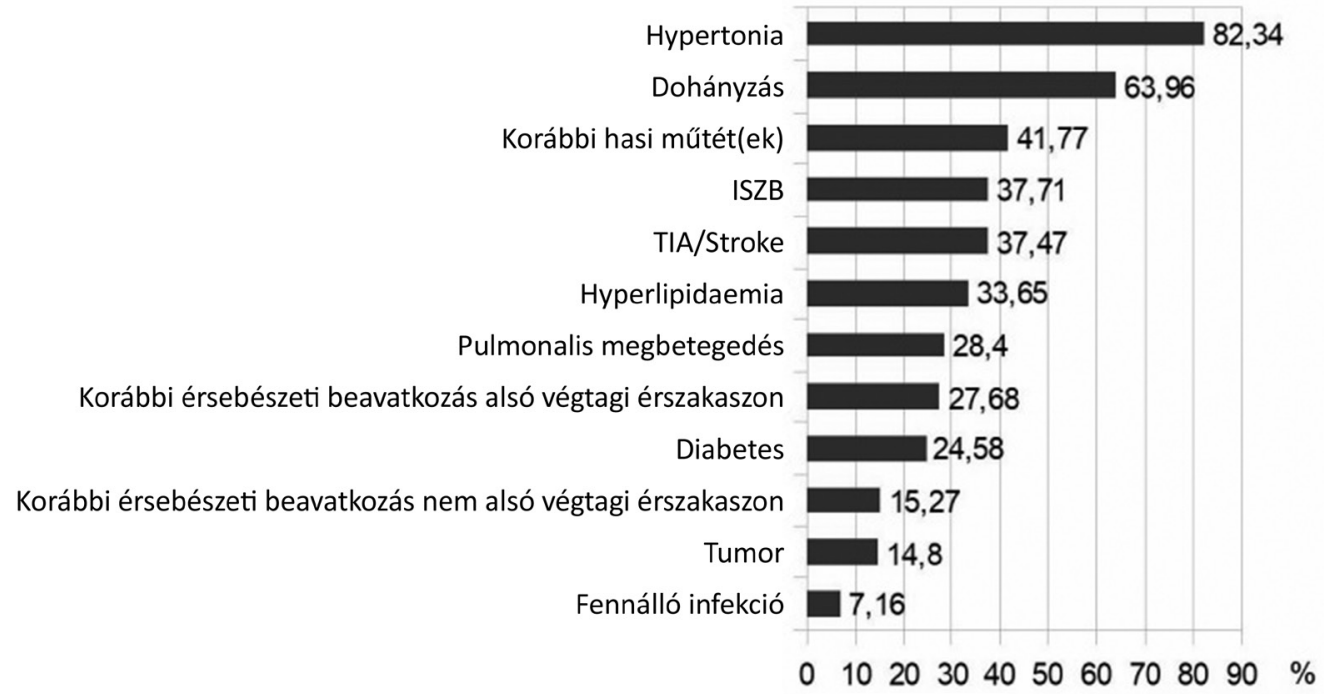

\begin{tabular}{l|l} 
1. ábra & $\begin{array}{l}\text { A fontosabb rizikótényezók, kísérő betegségek és releváns anamnesztikus adatok } \\
\text { ISZB = ischaemiás szívbetegség; TIA = átmeneti agyi keringészavar }\end{array}$
\end{tabular} 


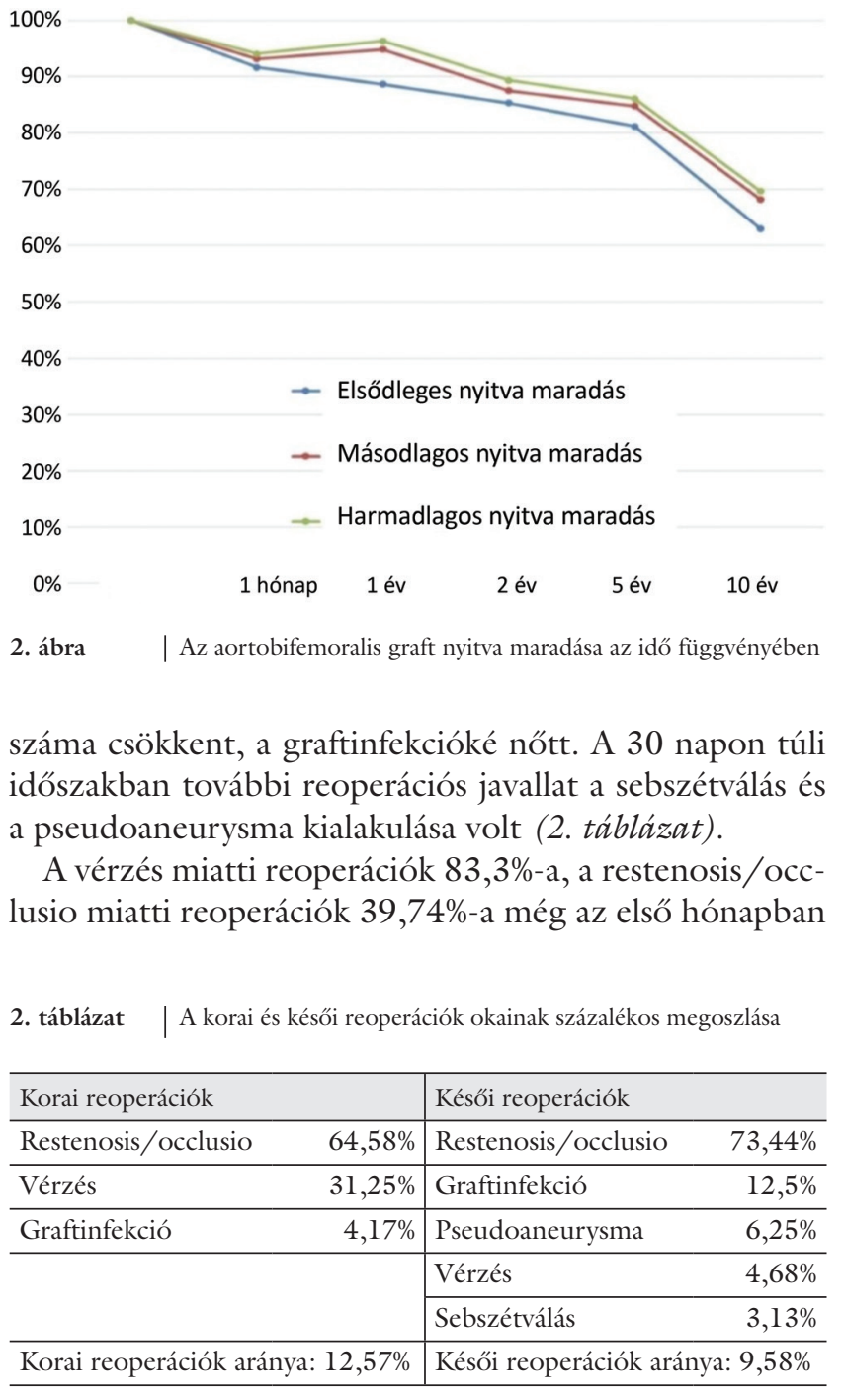

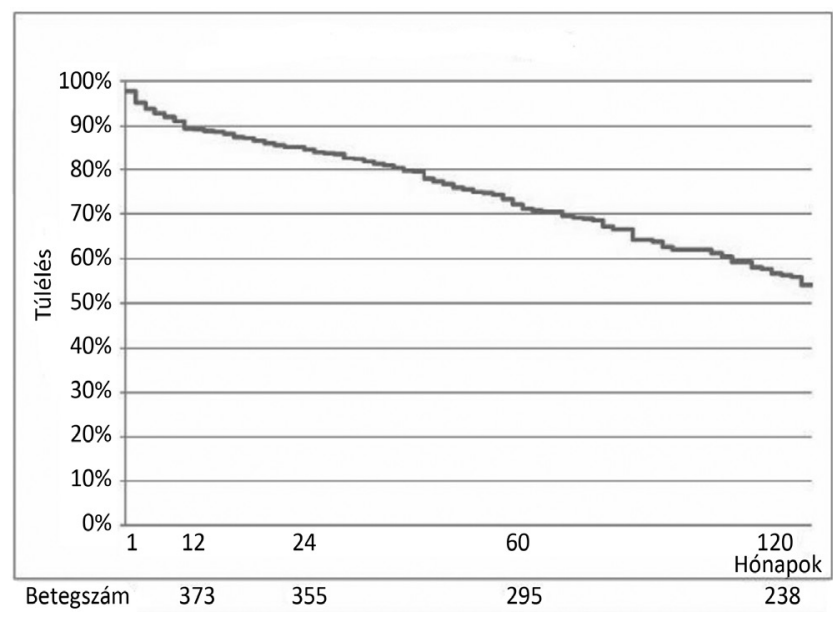

3. ábra |A betegek Kaplan-Meier-féle túlélési görbéje

megtörtént. A graftinfekciók 50\%-a az első 12 hónapon belül jelentkezett.

A posztoperatív első hónapon belül a kialakult, újabb mútétet nem igénylő szövődmények között az első három helyen a kardiológiai szövődmények, a gastrointestinalis szövődmények és az intenzív osztályon szerzett pneumonia állnak. A korai összmorbiditás magas, megközelíti a 26\%-ot (3. táblázat).

A késői morbiditási listát a mútétet igénylő posztoperatív hernia vezeti. Ezt követik a cardialis szövődmények, majd a nyirokelfolyási zavarok. A késői összmorbiditás $28,7 \%$-os.

$\mathrm{Az}$ atherosclerosis progresszióját vizsgálva azt találtuk, hogy 35 beteg esetében volt szükség a késóbbiekben a grafttól távolabbi érszakaszon további áthidaló beavatkozásra, 25 esetben femoropoplitealis, 6 esetben popli-

3. táblázat |Korai és késői morbiditási adatok

\begin{tabular}{|c|c|c|c|}
\hline \multicolumn{2}{|l|}{ Korai morbiditás } & \multicolumn{2}{|l|}{ Késői morbiditás } \\
\hline Szövődmény & Esetszám (fó) & Szövődmény & Esetszám (fó) \\
\hline Kardiológiai szövődmény & 21 & Posztoperatív hernia & 28 \\
\hline Gastrointestinalis szövődmény & 12 & Kardiológiai szövődmény & 13 \\
\hline Posztoperatív pneumonia & 10 & Nyirokelfolyási zavar & 12 \\
\hline Nyirokelfolyási zavar & 7 & Krónikus veseelégtelenség & 9 \\
\hline Disruptio & 7 & Aortoenteralis fistula & 8 \\
\hline Sebfertőzés & 6 & Sebfertőzés & 5 \\
\hline Kompartmentszindróma & 6 & Gastrointestinalis szövődmény & 4 \\
\hline Stroke & 5 & Stroke & 4 \\
\hline Húgyúti fertőzés & 2 & Disruptio & 3 \\
\hline Akut veseelégtelenség & 2 & Sipoly bőrben és bőr alatt & 3 \\
\hline Lépsérülés & 2 & Zsírnecrosis & 2 \\
\hline Uretersérülés & 2 & Lágyéki haematoma & 2 \\
\hline Zsírnecrosis & 1 & Leszakadt graft & 2 \\
\hline Akut mellékvese-elégtelenség & 1 & Mélyvénás thrombosis & 1 \\
\hline Mélyvénás thrombosis & 1 & & \\
\hline Retroperitonealis haematoma & 1 & & \\
\hline Összesen: & $86(25,75 \%)$ & Összesen: & $96(28,74 \%)$ \\
\hline
\end{tabular}


4. táblázat |A túlélési arány változása az idő függvényében

\begin{tabular}{ccccc}
\hline 1 hónapos & 1 éves & 2 éves & 5 éves & 10 éves \\
\hline $95,00 \%$ & $89,00 \%$ & $84,70 \%$ & $70,40 \%$ & $56,70 \%$ \\
\hline
\end{tabular}

teocruralis, 4 fó esetében femorocruralis bypasst végeztek. A beavatkozások 31,4\%-a a mútét utáni első hónapban történt. Az aortoiliacalis rekonstrukció ellenére 21 páciensnél vált szükségessé az amputáció, ami 6,29\%-os amputációs rátát okozott. Az amputációk többsége egy oldalon történt, 4 beteg esetében viszont mindkét oldali végtag-eltávolításra sor került. Az amputációk 57,14\%-ban femoralis, 35,71\%-ban cruralis szinten, $7,14 \%$-ban a boka szintje alatt történtek. Az amputációs beavatkozások 35,7\%-a 1 hónapon belül, 71,4\%-a az első éven belül történt.

A mütéti időzítés függvényében vizsgálva a különbözó szövődmények alakulását, elmondható, hogy a reoperációk és a belgyógyászati szövődmények esetében nem volt szignifikáns különbség az elektív, a sürgető és az akut csoportok között, azonban szignifikánsan több ( $\mathrm{p}=$ 0,0001) amputáció történt a sürgető csoportban az elektív esetekhez képest, valamint borderline szignifikánsan $(\mathrm{p}=0,056)$ több volt az amputációk száma az akut csoportban az elektívhez viszonyítva.

A betegek túlélését Kaplan-Meier-görbén ábrázolva látható a mútét után eltelt hónapok során fokozatosan fogyatkozó betegszám, illetve hogy a 10. év végére a túlélés kisebb mint $60 \%$ (3. ábra).

A közvetlen posztoperatív mortalitás 5,01\%. A mortalitás az évek során folyamatosan emelkedik, a 10. év végére eléri a 43,3\%-ot (4. táblázat).

\section{Megbeszélés}

Eredményeink alapján megállapítjuk, hogy a graft hoszszú távú primer nyitva maradása jó, 5 év után is $81 \%$, a megmentett végtagok aránya magas: 93,7\%. A posztoperatív első hónapban tapasztalt 5\%-os mortalitás nem elhanyagolható. Szintén ebben az időszakban a leggyakoribb az elzáródás és vérzés miatti reoperációk száma, valamint magas a korai morbiditás (26\%), gyakoriak a posztoperatív cardialis szövődmények, így ekkor a betegek szorosabb kontrollja ajánlott. A magas, 43,3\%-os 10 éves összmortalitás a betegség szisztémás jellegét mutatja, és magyarázza ezt a betegek idős kora és rossz általános állapota, számos kísérő betegsége. A nemzetközi eredményekkel összehasonlítva elmondható, hogy klinikánk beteganyagában magasabb az átlagéletkor a mútét idején, több rizikófaktorral kell számolni, így a morbiditási és mind a rövid, mind a hosszú távú mortalitási adatok is rosszabbak. A megmentett végtagok aránya közel azonos; az elsődleges és másodlagos nyitva maradás az első 2 évben megegyezik a nemzetközi eredményekkel, de az 5 éves nyitva maradás azokhoz képest már elmarad [3-8]. Davies és mtsai 1990-ben arról számoltak be, hogy az akkor még viszonylag újnak számító endovascularis technika bevezetése több, AIOD-ban szenvedő beteg kezelését tette lehetővé, hangsúlyozzák azonban a nyitott mütéti rekonstrukció jelentőségét az előrehaladott esetekben [9]. Az utóbbi években több publikáció jelent meg arról, hogy az endovascularis technika ideális lehet diffúz betegségben is, főleg a mütét szempontjából nagy rizikójú betegcsoportban [10-12]. Hazai ABBeredményeinket a nemzetközi cikkekben leírt endovascularis eredményekkel összehasonlítva azt találtuk, hogy az 1, 2 és 5 éves elsődleges nyitva maradás közel hasonló értékeket mutat, míg a másodlagos nyitvamaradási adatok rosszabbak, mint az endovascularis technikák esetében. Nyitott mútéteink mortalitása és morbiditása jóval magasabbnak bizonyult [13-19]. Vizsgálatunkban azoknak a betegeknek az adatait dolgoztuk fel, akik primer ABB-mütéten estek át. A Danczyk és mtsai által 2012ben kiadott összehasonlító tanulmány szerint azon betegek túlélése magasabb volt, akik először endovascularis beavatkozáson estek át, késóbb viszont nyitott mútétre szorultak, mint azoké, akik primeren nyitott mütéten estek át [4]. A TASC II. ajánlás ma a nyitott mútét szempontjából magas kockázatúnak minősülő esetekre egyértelműen javasolja az endovascularis mód előnyben részesítését. Antonello és mtsai azonban az alacsony kockázatú esetekben (alacsony kockázatú esetnek minősül az SVS által meghatározott $\leq 0,7$ komorbiditási pontszám és a $<75$ életkor) is az endovascularis beavatkozást javasolják [20]. 2019. évi tanulmányuk a nyitott mütét eredményeit hasonlítja össze a fedett sztent alkalmazásával ebben a betegcsoportban. Eredményeik alapján az aortoiliacalis obstruktív elváltozások esetén alacsony kockázatú és fiatalabb (<60 év) betegek esetén fedett sztenttel a nyitott mútéthez hasonló nyitvamaradási értékeket lehet elérni, lényegesen jobb perioperatív mortalitással, rövidebb kórházi ápolással és hosszú távon jó nyitva maradással. A tanulmány szerint a női nem rizikófaktornak számít kis kockázatú esetekben a restenosis szempontjából, így a nők esetén azonban a nyitott mütét továbbra is a választandó kezelési mód TASC II. D occlusiv elváltozásoknál [20]. Ezenfelül az elmúlt években egyre több összehasonlító publikáció jelenik meg a témában, melyek hasonló konklúzióra jutnak, miszerint az első posztoperatív évben a primer nyitva maradás tekintetében az endovascularis 'kissing' sztent technika és nyitott mütét hasonló értékeket produkál. A második év után a nyitott műtéttel megegyező nyitvamaradási adatok azonban csak reintervencióval nyerhetők. Az endovascularis technika után a későbbiekben is többször van szükség reintervencióra. Karpenko és mtsai 2016. évi tanulmánya szerint ez kifejezetten igaz azokra a betegekre, akik diabetesesek, illetve a femoropoplitealis szakasz is érintett a diffúz betegségben, fóleg a 100 mm-nél hoszszabb szúkült szakasz esetében [21]. A hosszú távú primer nyitva maradás tekintetében a nyitott mütét eredményei bizonyulnak jobbnak. A szövődmények kialakulásának szempontjából, így a mütét utáni hospitali- 
záció hosszának tekintetében, fóleg a posztoperatív elsó hónapban az endovascularis beavatkozás előnyösebb. Az összmorbiditás és -mortalitás a nyitott mütét esetében lényegesen rosszabb eredményeket mutat [22-27]. Bár a bypass hosszú távú eredményei elfogadhatók, súlyos komplikációk gyakrabban fordulnak elő. A mütétet igénylő eset bonyolultsága és a beavatkozást megelőző endovascularis terápia előre jelzi a későbbi komplikációk előfordulását. A hosszú távú túlélést a végtagi ischaemia mértéke és a társbetegségek egyértelmúen befolyásolják. Ezeket a tényezőket mindenképpen figyelembe kell venni a terápiás modalitás megválasztásakor [28]. Az endovascularis intervenció után a posztoperatív első hónapban Thomas és Leitman 2018. évi publikációja szerint a nyílt seb jelenléte, a dohányzás, a beavatkozást megelőző időszakban zajló szteroidterápia, a diabetes, a női nem, a magas szérumlipid- és fehérvérsejt-koncentráció és az alacsony szérumalbuminszint a leginkább meghatározó rizikófaktorok [22].

Az irodalmi adatok alapján TASC II. C, D esetekben az endovascularis technika primer alkalmazása általánosságban előnyösebb lehet még hosszú szakaszú aortoiliacalis betegség esetén is, de erről kevés hazai adat áll rendelkezésre [29], összehasonlító vizsgálat nincs. A különböző populációk vizsgálata az eltérô súlyosság (Fontaine-stádium), akut vs. krónikus állapot, a betegség kiterjedése mértékének megítélési nehézségei miatt körülményes.

\section{Következtetés}

Összefoglalásként elmondható, hogy az aortobifemoralis bypass a mai napig széleskörűen alkalmazott kezelés a hosszú szakaszú AIOD-ban szenvedő páciensek körében. Eredményeink és nemzetközi hosszú távú nyitvamaradási adatok is alátámasztják e terápiás módszer alkalmasságát. A nyitott hasi mütét nagy megterhelést jelent a sokszor idős, rossz általános állapotú, cardiovascularisan terhelt betegek számára. Ezek a tényezők együttesen a mütét jelentős korai és késői morbiditását és mortalitását okozzák . Nem meglepő, hogy napjainkban egyre inkább előtérbe kerülnek a pácienseket összességében kevésbé igénybe vevő minimálinvazív intervenciós radiológiai módszerek, melyeknek a megjelent publikációk alapján helyük van a nyitott mútéti technika mellett. Mindezek ismeretében érdemes lenne a hazai gyakorlatban is szélesebb körben bevezetni a kisebb megterheléssel járó endovascularis mútéteket, megfelelő feltételek mellett akár hosszú szakaszú aortobiiliacalis elváltozás esetén is. További következtetések természetesen csak a hazai endovascularis technika eredményeinek és annak a nyitott mütéttel történő összehasonlító feldolgozása után mondhatók ki.
Anyagi támogatás: A közlemény megírása, illetve a kapcsolódó kutatómunka anyagi támogatásban nem részesült.

Szerzői munkamegosztás: P. E.: A kutatómunka megtervezése, adatgyưjtés, adatelemzés, statisztikai számítás, irodalmi összehasonlítás és a kézirat megírása. L. B., O. P., N. D. T.: Adatgyűjtés, adatelemzés, irodalmi összehasonlítás és a kézirat megírása, javítása. Sz. Z.: A kutatómunka megtervezése, a cikk végleges változatának véleményezése, javítása és jóváhagyása. A cikk végleges változatát valamennyi szerző elolvasta és jóváhagyta.

Érdekeltségek: A szerzőknek nincsenek érdekeltségeik.

\section{Irodalom}

[1] Sidawy AN, Perler BA. (ed.) Rutherford's Vascular Surgery and Endovascular Therapy. Elsevier, Philadelphia, PA, 2018.

[2] Norgren L, Hiatt WR, Dormandy JA, et al. Inter-society consensus for the management of peripheral arterial disease (TASC II). J Vasc Surg. 2007; 45(Suppl): S5-S67.

[3] de Vries SO, Hunink MG. Results of aortic bifurcation grafts for aortoiliac occlusive disease: a meta-analysis. J Vasc Surg. 1997; 26: 558-569.

[4] Danczyk RC, Mitchell EL, Petersen BD, et al. Outcomes of open operation for aortoiliac occlusive disease after failed endovascular therapy. Arch Surg. 2012; 147: 841-845.

[5] Lee GC, Yang SS, Park KM, et al. Ten year outcomes after bypass surgery in aortoiliac occlusive disease. J Korean Surg Soc. 2012; 82: 365-369.

[6] Ozcan AV, Emrecan B, Gökşin I. Aortobifemoral bypass via paramedian incision and retroperitoneal approach for aortoiliac occlusive disease. Acta Chir Belg. 2013; 113: 182-186.

[7] Reed AB, Conte MS, Donaldson MC, et al. The impact of patient age and aortic size on the results of aortobifemoral bypass grafting. J Vasc Surg. 2003; 37: 1219-1225.

[8] Sharma G, Scully RE, Shah SK, et al. Thirty-year trends in aortofemoral bypass for aortoiliac occlusive disease. J Vasc Surg. 2018; 68: 1796-1804.e2.

[9] Davies AH, Ramarakha P, Collin J, et al. Recent changes in the treatment of aortoiliac occlusive disease by the Oxford Regional Vascular Service. Br J Surg. 1990; 77: 1129-1131.

[10] Ali AT, Modrall GJ, Lopez J, et al. Emerging role of endovascular grafts in complex aortoiliac occlusive disease. J Vasc Surg. 2003; 38: 486-491.

[11] Mouanoutoua M, Maddikunta R, Allaqaband S, et al. Endovascular intervention of aortoiliac occlusive disease in high-risk patients using the kissing stents technique: long-term results. Catheter Cardiovasc Interv. 2003; 60: 320-326.

[12] Rzucidlo EM, Powell RJ, Zwolak RM, et al. Early results of stent-grafting to treat diffuse aortoiliac occlusive disease. J Vasc Surg. 2003; 37: 1175-1180.

[13] Jongkind V, Akkersdijk GJ, Yeung KK, et al. A systematic review of endovascular treatment of extensive aortoiliac occlusive disease. J Vasc Surg. 2010; 52: 1376-1383

[14] Tiek J, Remy P, Sabbe T, et al. Laparoscopic versus open approach for aortobifemoral bypass for severe aorto-iliac occlusive disease. A multicentre randomised controlled trial. Eur J Vasc Endovasc Surg. 2012; 43: 711-715.

[15] Indes JE, Pfaff MJ, Farrokhyar F, et al. Clinical outcomes of 5358 patients undergoing direct open bypass or endovascular 
treatment for aortoiliac occlusive disease: a systematic review and metaanalysis. J Endovasc Ther. 2013; 20: 443-455.

[16] Dorigo W, Piffaretti G, Benedetto F, et al. A comparison between aortobifemoral bypass and aortoiliac kissing stents in patients with complex aortoiliac obstructive disease. J Vasc Surg. 2017; 65: 99-107.

[17] Groot Jebbink E, Holewijn S, Slump CH, et al. Systematic review of results of kissing stents in the treatment of aortoiliac occlusive disease. Ann Vasc Surg. 2017; 42: 328-336.

[18] Groot Jebbink E, Holewijn S, Versluis M, et al. Meta-analysis of individual patient data after kissing stent treatment for aortoiliac occlusive disease. J Endovasc Ther. 2019; 26: 31-40,

[19] Quan C, Kim DH, Jung HJ, et al. Comparison of results between kissing stent and aortic bifurcated bypass in aortoiliac occlusive disease. Asian J Surg. 2020; 43: 186-192.

[20] Antonello M, Squizzato F, Bassini S, et al. Open repair versus endovascular treatment of complex aortoiliac lesions in low risk patients. J Vasc Surg. 2019; 70: 1155-1165.el.

[21] Karpenko AA, Starodubtsev VB, Ignatenko PV, et al. Results of endovascular interventions in patients with occlusive stenotic lesions of arteries of the aortoiliac segment. Angiol Sosud Khir. 2016; 22: 77-82. [Russian]

[22] Thomas AT, Leitman IM. Predictors of serious morbidity and mortality after endovascular repair of aortoiliac lesions. Surgery 2018; 164: 365-369.

[23] Pepe RJ, Patel P, Huntress LA, et al. Endovascular reconstruction for chronic infrarenal aortoiliac occlusive disease. Ann Vasc Surg. 2017; 45: 263.e211-263.e217.
[24] Van Haren RM, Goldstein LJ, Velazquez OC, et al. Endovascular treatment of TransAtlantic Inter-Society Consensus D aortoiliac occlusive disease using unibody bifurcated endografts. J Vasc Surg. 2017; 65: 398-405.

[25] Bracale UM, Giribono AM, Spinelli D, et al. Long-term results of endovascular treatment of TASC C and D aortoiliac occlusive disease with expanded polytetrafluoroethylene stent graft. Ann Vasc Surg. 2019; 56: 254-260.

[26] Gabel JA, Kiang SC, Abou-Zamzam AM Jr, et al. Trans-Atlantic Inter-Society Consensus class D aortoiliac lesions: a comparison of endovascular and open surgical outcomes. Am J Roentgenol. 2019; 213: 696-701.

[27] Mayor J, Branco BC, Chung J, et al. Outcome comparison between open and endovascular management of TASC II D aortoiliac occlusive disease. Ann Vasc Surg. 2019; 61: 65-71.e3.

[28] DeCarlo C, Boitano LT, Schwartz SI, et al. Operative complexity and prior endovascular intervention negatively impact morbidity after aortobifemoral bypass in the modern era. Ann Vasc Surg. $2020 ; 62: 21-29$

[29] Vértes M, Juhász IZ, Nguyen TD, et al. Stent protrusion $>20$ $\mathrm{mm}$ into the aorta: a new predictor for restenosis after kissing stent reconstruction of the aortoiliac bifurcation. J Endovasc Ther. 2018; 25: 632-639.

(Szeberin Zoltán dr., Budapest, Városmajor u. 68., 1122 e-mail: zszeberin@yahoo.com)

\section{"Quod fugere credas saepe solet occurrere." (Amiről azt hinnénk, már múlóban van, gyakran bukkan fel újra hirtelen.)}

A cikk a Creative Commons Attribution 4.0 International License (https://creativecommons.org/licenses/by/4.0/) feltételei szerint publikált Open Access közlemény, melynek szellemében a cikk bármilyen médiumban szabadon felhasználható, megosztható és újraközölhetö, feltéve, hogy az eredeti szerző és a közlés helye, illetve a CC License linkje és az esetlegesen végrehajtott módosítások feltüntetésre kerülnek. (SID_1) 